Situs Jurnal : $\underline{\text { http://ejurnal.stiepancasetia.ac.id/index.php/jieb }}$

Jilid 5 Nomor 1 Maret 2019

Hal $129-142$

\title{
ANALISIS LAPORAN KEUANGAN DAERAH TERHADAP KINERJA KEUANGAN PADA PEMERINTAH DAERAH KABUPATEN TANAH BUMBU
}

\section{Ifrita Indah Sari dan Imawati Yousida*}

Abstract: The purpose of this study was to find out the regional financial performance of the Tanah Bumbu district government in 2015 - 2017. This research is a case study study with data collection using documentation techniques and data used are secondary data in the form of Regional Revenue and Expenditure Budget Realization in Tanah Bumbu Regency 2015 - 2017. Furthermore, this data is analyzed using financial ratios, namely the degree of decentralization, regional dependency ratio, regional financial independence ratio, effectiveness ratio of regional original income, efficiency ratio of local original revenue, growth ratio, harmony ratio and Debt service coverage ratio (DSCR). The results of the study indicate that in general the financial performance of the Tanah Bumbu District Government is good. This shows that the average decentralization degree is low, the regional dependency ratio is very high, the regional independence ratio is still low, the ratio of effectiveness of local revenue is effective, the efficiency ratio of local original revenue is efficient, the ratio of growth to funding allocation is good. operating expenses rather than capital expenditure. Debt service coverage ratio (DSCR) is good.

Keywords: Financial performance, financial ratio

Abstrak: Tujuan Penelitian ini adalah untuk mengetahui kinerja keuangan daerah pemerintah daerah kabupaten Tanah Bumbu tahun 2015 - 2017. Penelitian ini merupakan penelitian studi kasus dengan pengumpulan data menggunakan teknik dokumentasi dan data yang digunakan adalah data sekunder berupa Laporan Realisasi Anggaran Pendapatan dan Belanja Daerah Kabupaten Tanah Bumbu tahun 2015 - 2017. Selanjutnya data ini dianalisis dengan menggunakan rasio keuangan yaitu derajat desentralisasi, rasio ketergantungan daerah,rasio kemandirian keuangan daerah, rasio efektivitas pendapatan asli daerah, rasio efisiensi pendapatan asli daerah, rasio pertumbuhan, rasio keserasian dan Debt service coverage ratio (DSCR). Hasil penelitian menunjukkan bahwa secara umum kinerja keuangan Pemerintah Daerah Kabupaten Tanah Bumbu baik. Hal ini menunjukkan dengan rata-rata derajat desentralisasi rendah, rasio ketergantungan daerah sangat tinggi, rasio kemandirian daerah masih rendah, rasio efektivitas pendapatan asli daerah sudah efektif, rasio efisiensi pendapatan asli daerah efisien,rasio pertumbuhan pendapatan baik, rasio keserasian terhadap alokasi dana lebih mendominasi belanja operasi dari pada belanja modal. Debt service coverage ratio (DSCR) baik

Kata kunci : Kinerja keuangan, Rasio keuangan.

\section{Latar Belakang}

Pemerintahan merupakan suatu organisasi yang diberi kekuasaan untuk mengatur kepentingan bangsa dan negara. Lembaga pemerintah dibentuk umumnya untuk menjalankan aktivitas layanan terhadap masyarakat luas dan sebagai organisasi nirlaba yang mempunyai 
tujuan bukan mencari keuntungan tetapi untuk menyediakan layanan dan kemampuan meningkatkan pelayanan tersebut di masa yang akan datang.

Dalam rangka desentralisasi dibentuk dan disusun pemerintah provinsi dan pemerintah kota/kabupaten yang diberikan kewenangan untuk mengatur dan mengurus rumah tangganya sebagai perwujudan otonomi daerah. Akuntabilitas merupakan dasar pelaporan keuangan di pemerintahan. Pengelolaan keuangan pemerintah daerah harus dilakukan berdasarkan tata kelola kepemerintahan yang baik (good governance goverment), yaitu pengelolaan keuangan yang dilakukan secara transparan dan akuntabel, yang memungkinkan para pemakai laporan keuangan untuk dapat mengakses informasi tentang hasil yang dicapai dalam penyelenggaraan pemerintahan daerah.

Kemampuan Pemerintah Daerah dalam mengelola keuangan dituangkan dalam Anggaran Pendapatan dan Belanja Daerah (APBD), dalam Anggaran Pendapatan dan Belanja Daerah mencerminkan kemampuan pemerintah dalam membiayai pelaksanaan tugas-tugas pemerintah, pembangunan, dan pelayanan sosial masyarakat.

Analisis rasio keuangan adalah suatu ukuran untuk mengidentifikasi ciri-ciri keuangan berdasarkan laporan keuangan pada pemerintah daerah yang tersedia untuk menilai kemandirian keuangan daerah dalam membiayai penyelenggaraan otonomi daerah, mengukur efektifitas dan efisiensi dalam merealisasikan pendapatan daerah, mengukur sejauh mana aktifitas pemerintah daerah dalam membelanjakan pendapatan daerah, melihat kontribusi masing-masing sumber pendapatan dalam pembentukan pendapatan daerah, melihat pertumbuhan dan perkembangan perolehan pendapatan serta pengeluaran yang dilakukan selama periode tertentu.

Untuk mengetahui kesiapan suatu daerah dalam menghadapi otonomi daerah, maka perlu dilakukan suatu analisis terhadap kinerja pemerintah daerah dalam mengelola keuangan daerahnya demi mewujudkan tingkat kemandirian dalam era otonomi daerah. Laporan keuangan pemerintah kemudian disampaikan kepada DPRD dan masyarakat umum setelah diaudit oleh Badan Pemeriksa Keuangan (BPK). Adapun komponen laporan keuangan yang disampaikan tersebut meliputi Laporan Realisasi Anggaran, Neraca, Laporan Arus Kas, dan Catatan atas Laporan Keuangan.

Bentuk laporan pertanggungjawaban atas pengelolaan keuangan daerah selama satu tahun anggaran adalah dalam bentuk Laporan Keuangan Pemerintah Daerah (LKPD). Laporan keuangan pemerintah daerah harus mengikuti Standar Akuntansi Pemerintahan sesuai Peraturan Pemerintah No. 71 Tahun 2010. Tujuan diberlakukannya hal tersebut adalah agar lebih accountable dan semakin diperlukannya peningkatan kualitas laporan keuangan. Kualitas laporan keuangan pemerintah sangat dipengaruhi oleh faktor kepatuhan terhadap standar akuntansi, kapabilitas sumberdaya manusia, serta dukungan sistem akuntansi yang ada. Tidak pula terlepas dinamika perubahan eksternal yang tidak dapat dikendalikan oleh organisasi. Salah satu sumber penerimaan yang signifikan bagi pembiayaan rutin untuk membangun suatu daerah yang otonom adalah sumber pembiayaan yang berasal dari PAD. PAD merupakan pendapatan pemerintah daerah yang bersumber dari aktivitas komponen sumber daya ekonomi daerah yang berpotensi untuk dikelola secara maksimal meliputi hasil dari penerimaan pajak daerah, retribusi daerah, hasil pengelolaan kekayaan daerah yang dipisahkan serta lain-lain pendapatan asli daerah yang sah. Laporan keuangan yang berkualitas dapat dilihat dari hasil opini auditor pada laporan keuangan pemerintah daerah Kabupaten Tanah Bumbu tahun anggaran 2015, tahun anggaran 2016 sampai dengan 2017.

Berdasarkan latar belakang masalah di atas, maka peneliti tertarik untuk melakukan penelitian dengan judul "Analisis Laporan Keuangan Daerah terhadap Kinerja Keuangan pada Pemerintah Daerah Kabupaten Tanah Bumbu Tahun anggaran 2015-2017”. 


\section{Kajian Literatur}

Keuangan dan anggaran daerah merupakan alat fiskal pemerintahan daerah, adalah bagian integral dari keuangan negara. Oleh karena itu, pengalokasian sumber keuangan diperuntukan bagi pemerataan pembangunan sekaligus menciptakan stabilitas ekonomi daerah, sehingga peranan keuangan dan anggaran daerah akan semakin penting di samping keterbatasan pendapatan asli daerah dalam mengimbangi perolehan dana dari pemerintah pusat, tetapi juga dikarenakan semakin kompleksnya permasalahan yang dihadapi daerah dalam mengakomodasi potensi serta pemecahannya, yang membutuhkan peran aktif masyarakat daerah secara keseluruhan.

Value for money merupakan ekspresi pelaksanaan lembaga sektor publik yang mendasarkan pada tiga elemen dasar yaitu : ekonomi, efisien, dan efektivitas, untuk itu maka pengelolaan keuangan daerah merupakan isu utama dalam pencapaian tujuan pemerintahan yang bersih (clean goverment), dan manajemen pengelolaan keuangan daerah yang baik adalah yang mampu mengontrol kebijakan keuangan daerah secara ekonomis, efisien, efektif, transparan dan akuntabel.

Perbaikan kinerja anggaran dan pengelolaan keuangan daerah menduduki posisi penting dalam strategi pemberdayaan pemerintah daerah terlebih lagi menyongsong pelaksanaan otonomi daerah dan mewujudkan desentralisasi yang luas, nyata, dan bertanggungjawab. Secara metodologi agar kinerja sektor publik bagus, maka diperlukan manajemen berbasis kinerja pada organisasi sektor publik. Manajemen kinerja yang baik harus memiliki sistem pengukuran kinerja yang handal pula. Untuk memiliki sistem pengukuran kinerja yang handal dan berkualitas, maka diperlukan pengembangan indikator kinerja yang komprehensif. Pengembangan indikator kinerja itu meliputi indikator input, process, output, outcome, benefit, dan impact.

Sesuai dengan siklus akuntansi, setelah menyusun neraca saldo setelah penyesuaian, disusunlah laporan-laporan keuangan dengan mengambil data dari neraca saldo setelah penyesuaian. Berdasarkan Pasal 232 dari Permendagri No 13 Tahun 2006, Laporan keuangan Pemda berbasi kas terdiri atas:

1. Laporan realisasi anggaran

2. Neraca

3. Laporan arus kas

4. Catatan atas Laporan Keuangan

Namun demikian, pada organisasi Pemerintah Daerah laporan keuangan yang dikehendaki diatur oleh Peraturan Pemerintah Nomor 71 Tahun 2010 tentang Standar Akuntasi Pemerintahan, Permendagri Nomor 64 tahun 2013 tentang Penerapan SAP berbasis akrual pada Pemerintah Daerah, sesuai PP nomor 71 tahun 2010, laporan keuangan terdiri :

1. Laporan realisasi anggaran (LRA)

2. Laporan perubahan saldo anggaran lebih (LP SAL)

3. Neraca

4. Laporan operasional (LO)

5. Laporan arus kas (LAK)

6. Laporan perubahan ekuitas (LPE)

7. Catatan atas laporan keuangan (CaLK) 
Laporan Perhitungan APBD juga menunjukkan kinerja Pemda sebagai penyusun dan pelaksanaan APBD. Dengan demikian, laporan perhitungan APBD menyajikan pendapatan Pemda selama satu periode dan belanja untuk memperoleh pendapatan tersebut pada periode yang sama.

Kienerja adalah gambaran tingkat pencapaian pelaksanaan suatu kegiatan/program dalam mewujudkan sasaran, tujuan, visi dan misi organisasi yang tertuang dalam perumusan perencanaan strategis (Strategic planning) suatu organisasi. Keuangan daerah mempunyai arti yang sangat penting dalam rangka pelaksanaan pemerintahan dan kegiatan pembangunan oleh pelayanan kemasyarakatan di daerah, oleh karena itu keuangan daerah diupayakan untuk berjalan secara berdaya guna dan berhasil guna.

Secara umum istilah kinerja digunakan untuk menyebut prestasi atau tingkat keberhasilan individu maupun kelompok individu. Kinerja adalah gambaran mengenai tingkat pencapaian pelaksanaan suatu kegiatan atau program atau kebijakan dalam mewujudkan sasaran, tujuan, misi, dan visi organisasi yang tertuang dalam strategic planning suatu organisasi. Kinerja bisa diketahui hanya jika individu atau kelompok individu tersebut mempunyai kriteria keberhasilan yang telah ditetapkan. Kriteria keberhasilan ini berupa tujuantujuan atau target-target tertentu yang hendak dicapai.

Sedangkan menurut Moeheriono (2012:96), pengukuran kinerja (performance measurement) mempunyai pengertian suatu proses penilaian tentang kemajuan pekerjaan terhadap tujuan dan sasaran dalam pengelolaan sumber daya manusia untuk menghasilkan barang dan jasa, termasuk informasi atas efisiensi serta efektivitas tindakan dalam mencapai tujuan organisasi.

Kinerja Keuangan adalah gambaran kondisi keuangan pada periode tertentu yang diukur dengan beberapa indikator dan disusun berdasarkan basis akrual (Penyandingan pendapatan dan biaya pada periode disaat terjadinya). Selanjutnya dalam kaitannya dengan pemerintah daerah, Menurut Hendro Sumarjo dalam Tyas Nurulafifah (2012), "Kinerja Keuangan Pemerintah Daerah adalah keluaran atau hasil dari kegiatan atau program yang akan atau telah dicapai sehubungan dengan penggunaan anggaran daerah dengan kualitas dan kuantitas yang terukur, kemampuan daerah dapat diukur dengan menilai efisiensi atas pelayanan yang diberikan kepada masyarakat".

Menurut Mahmudi (2016:89), Analisis Laporan Keuangan adalah kegiatan untuk menginterprestasikan angka-angka yang terdapat pada laporan keuangan dalam rangka menilai kinerja keuangan yang hasil analisis tersebut akan digunakan sebagai dasar pengambilan keputusan ekonomi, sosial, atau politik.

Dalam rangka pengelolaan pemerintah daerah yang transparan, jujur, demokrasi, efektif, efisien, dan akuntanbel analisis kinerja keuangan daerah perlu dilakukan dengan mengunakan salah satu ukuran yaitu analisis rasio keuangan terhadap Anggaran Pendapatan dan Belanja Daerah (APBD). Hasil dari analisis rasio keuangan pemerintah daerah tersebut akan menunjukan kondisi dan kinerja keuangan daerah selama periode yang di analisis.

Rasio keuangan merupakan suatu perhitungan rasio dengan menggunakan laporan keuangan yang berfungsi sebagai alat ukur dalam menilai kondisi keuangan dan kinerja pemerintah. Rasio keuangan adalah angka yang diperoleh dari hasil perbandingan antara satu pos laporan keuangan dengan pos lainnya yang mempunyai hubungan relavan dan signifikan. Menurut Hery (2015:162), perbandingan yang dapat dilakukan antara satu pos dengan pos lainnya dalam satu laporan keuangan atau antar pos yang ada diantara laporan keuangan periode bersangkutan. 
Untuk mengukur kinerja, maka dilakukan perhitungan dengan menggunakan analisis rasio keuangan yang meliputi:

1. Rasio Derajat Desentralisasi Fiskal

Derajat desentralisasi merupakan salah satu rasio keuangan yang dapat digunakan untuk menunjukakan tingkat kewenangan dan tanggung jawab yang diberikan pemerintah pusat kepada pemerintah daerah untuk melaksanakan pembangunan. Menurut Mahmudi (2016:140), rasio ini menunjukan derajat kontribusi PAD terhadap total penerimaan daerah, semakin tinggi kontribusi PAD maka semakin tinggi pula kemampuan daerah dalam melaksanakan desentralisasi.

\section{DDF $=\underline{\text { Pendapatan Asli Daerah } \times 100 \%}$ \\ Total Pendapatan Daerah}

Tabel 1. Tabel Kategori Capaian Kinerja

\begin{tabular}{lll}
\hline No & Skala Ordinal & Ketegori \\
\hline 1 & Lebih dari $90 \%$ & Sangat Berhasil \\
\hline 2 & $81 \%$ s.d $90 \%$ & Baik (Berhasil) \\
\hline 3 & $61 \%$ s.d $80 \%$ & Cukup Berhasil \\
\hline 4 & Kurang dari $60 \%$ & Kurang Berhasil \\
\hline
\end{tabular}

\section{Sumber : Banga, 2017}

2. Rasio Ketergantungan Daerah

Ketergantungan adalah keadaan ketika suatu organisasi tergantung pada organisasi lainnya, sehingga organisasi tersebut tidak dapat memikul tanggung jawabnya sendiri. Dalam hal ini organisasi pemerintahan, terutama pemerintah daerah tergantung pada dana yang diberikan oleh pemerintah pusat/provinsi. Rasio ketergantungan keuangan daerah dapat dihitung dengan menggunakan rumus sebagai berikut:

$$
\text { Rasio Ketergantungan }=\frac{\text { Pendapatan Transfer }}{\text { Total Pendapatan Daerah }} \times 100 \%
$$

Kriteria untuk penilaian ketergantungan keuangan daerah dapat dilihat pada Tabel 2.

Tabel 2. Skala Interval

\begin{tabular}{ccc}
\hline NO & Persentase $\%$ & Kategori \\
\hline 1 & $0,00-10,00$ & Sangat Rendah \\
\hline 2 & $10,00-20,00$ & Rendah \\
\hline 3 & $20,01-30,00$ & Sedang \\
\hline 4 & $30,01-40,00$ & Cukup \\
\hline 5 & $40,01-50,00$ & Tinggi \\
\hline 6 & $>50,00$ & Sangat Tinggi \\
\hline
\end{tabular}

Sumber : Banga, 2017 
1. Rasio Kemandirian Daerah

Rasio kemandirian daerah dihitung dengan cara membandingkan jumlah penerimaan pendapatan asli daerah dengan jumlah pendapatan transfer dari pemerintah pusat dan provinsi serta pinjaman daerah, semakin tinggi persentase rasio maka rasio ini menunjukan semakin tinggi tingkat kemandirian daerahnya. Rasio kemandirian daerah dapat dihitung dengan menggunakan rumus sebagai berikut:

Rasio Kemandirian $=\frac{\text { Pendapatan Asli Daerah }}{\text { Trf Pusat }+ \text { Provinsi }+ \text { Pinjaman }} \times 100 \%$

Pengelolan rasio kemandirian daerah yang berhasil guna dan tepat guna dapat dikaji dalam bentuk interval seperti diperlihatkan pada Tabel 3.

Tabel 3. Skala Interval Rasio Kemandirian Daerah

\begin{tabular}{lll}
\hline NO & Persentase $(\%)$ & Kategori \\
\hline 1 & $0,00-10,0$ & Sangat Kurang \\
\hline 2 & $10,00-20,00$ & Kurang \\
\hline 3 & $20,01-30,00$ & Sedang \\
\hline 4 & $30,01-40,00$ & Cukup \\
\hline 5 & $40,00-50,00$ & Baik \\
\hline 6 & $>50$ & Sangat Baik \\
\hline
\end{tabular}

Sumber: Permendagri Nomor 37 Tahun 2014

2. Rasio Efektifitas Pendapatan Asli Daerah dan Pajak Daerah

Rasio Efektivitas PAD dihitung dengan cara membandingkan realisasi penerimaan PAD dengan target penerimaan PAD yang di anggarkan. Rumus rasio efektifitas PAD dapat dihitung sebagai berikut:

Rasio Efektivitas Pajak daerah $=\underline{\text { Realisasi Penerimaan Pajak Daerah }} \times 100 \%$ Target Penerimaan Pajak Daerah

Tabel 4. Skala Interval Rasio Efektifitas PAD dan Pajak daerah

\begin{tabular}{ccc}
\hline NO & Persentase $(\%)$ & Kategori \\
\hline 1 & $>100 \%$ & Sangat Efektif \\
\hline 2 & $100 \%$ & Efektif \\
\hline 3 & $90 \%-99 \%$ & Cukup Efektif \\
\hline 4 & $75 \%-89 \%$ & Kurang Efektif \\
\hline 5 & $<75 \%$ & Tidak Efektif \\
\hline
\end{tabular}

Sumber : Mahmudi, 2016

3. Rasio Efisiensi Pendapatan Asli Daerah dan Pajak Daerah

Penghitungan rasio efisiensi adalah dengan cara membandingkan biaya yang dikeluarkan pemerintah daerah untuk memperoleh PAD dengan realisasi PAD yang diterima. Rumus Rasio Efisiensi PAD sebagai berikut: 
$\begin{aligned} \text { Rasio Efisiensi PAD = } & \begin{array}{c}\text { Biaya Perolehan PAD } \times 100 \% \\ \text { Realisasi Penerimaan PAD }\end{array}\end{aligned}$

Rumus Efisiensi Pajak Daerah sebagai berikut:

Rasio Efisiensi Pajak Daerah $=\frac{\text { Biaya Pemungutan Pajak Daerah }}{\text { Realisasi Penerimaan Pajak Daerah }} \times 100 \%$

Nilai efisiensi PAD dan efisiensi pajak daerah dapat dilihat dalam tabel skala interval pada Tabel 5.

Tabel 5. Skala Interval Rasio Efisien

\begin{tabular}{|c|c|c|}
\hline $\mathrm{NO}$ & Persentase $(\%)$ & Kategori \\
\hline 1 & $<10 \%$ & Sangat Efisien \\
\hline 2 & $10 \%-20 \%$ & Efisien \\
\hline 3 & $21 \%-30 \%$ & Cukup Efisien \\
\hline 4 & $31 \%-40 \%$ & Kurang Efisien \\
\hline 5 & $>40 \%$ & Tidak Efisien \\
\hline
\end{tabular}

4. Rasio Pertumbuhan

Rasio pertumbuhan (Growth ratio) digunakan untuk mengukur seberapa besar kemampuan pemerintah daerah dalam mempertahankan dan meningkatkan keberhasilan yang telah dicapai dari tahun ke tahun melalui masing-masing komponen sumber pendapatan dan pengeluaran, yang dapat digunakan untuk mengevaluasi potensi-potensi mana yang perlu mendapatkan perhatian. Rumus yang dapat digunakan untuk mengukur rasio ini sebagai berikut:

$\begin{aligned} \text { Pertumbuhan PAD th } \mathrm{t}= & \text { PADTt }- \text { PADTt } 1 \times 100 \% \\ & \text { PADTt } 1\end{aligned}$

Per Belanja Tht $=\underline{\text { Real BelanjaTt }- \text { Real BelanjaTt-1 }} \times 100 \%$

Realisasi Belanja Thn t-1

Indikator terhadap rasio pertumbuhan dapat dilihat pada tabel 6.

Tabel 6.

\begin{tabular}{ccc}
\hline NO & Persentase $(\%)$ & Kategori \\
\hline 1 & $0 \%-50 \%$ & Baik/Positif \\
\hline 2 & $<0 \%$ & Kurang Baik/Negatif \\
\hline
\end{tabular}

5. Rasio Keserasian

Rasio ini menggambarkan bagaimana Pemerintah Daerah memprioritaskan alokasi dananya pada belanja operasi dan belanja modal secara optimal. Semakin tinggi persentase dana yang di alokasikan untuk belanja operasi berarti persentase belanja investasi (belanja modal) yang digunakan untuk menyediakan sarana dan prasarana ekonomi masyarakat cenderung 
semakin kecil. Menurut Mahmudi (2016:162), Rasio keserasian dapat diformulasikan sebagai berikut:

Ras. Belanja Operasi = Total Belanja Operasi x 100\%

Total Belanja Daerah

Ras. Belanja Modal $=$ Total Belanja Modal x 100\%

Total Belanja Daerah

Indikator terhadap rasio ini dapat dilihat melalui tabel 7.

Tabel 7. Skala Interval Rasio Keserasian

\begin{tabular}{ccc}
\hline NO & $\begin{array}{c}\text { Persentase } \\
(\%)\end{array}$ & Kategori \\
\hline 1 & $>100 \%$ & Tidak Baik \\
\hline 2 & $90 \%-100 \%$ & Kurang Baik \\
\hline 3 & $80 \%-90 \%$ & Cukup Baik \\
\hline 4 & $60 \%-80 \%$ & Baik \\
\hline 5 & $<60 \%$ & Sangat Baik \\
\hline
\end{tabular}

Mahmudi 2016

6. Debt Service Coverage Ratio (DSCR)

Rasio yang digunakan untuk mengukur kemampuan Pemerintah Daerah dalam

membayar kembali pinjaman daerah. Rasio ini dirumuskan sebagai berikut:

DSCR = Rasio yang digunakan untuk mengukur kemampuan Pemerintah Daerah dalam membayar kembali pinjaman daerah.

Rasio ini dirumuskan sebagai berikut:

$\mathrm{DSCR}=((\mathrm{PAD}+\mathrm{BD}+\mathrm{DAU})-\mathrm{BW}) /($ Total $($ Pokok Angsuran+Bunga+Biaya Pinjaman $))$

Berdasarkan rasio ini, Pemerintah Daerah dinilai layak untuk melakukan pinjaman daerah apabila nilai DSCR-nya minimal 2,5.

Tabel 8. Skala Interval Debt Service Coverage Ratio

\begin{tabular}{ccc}
\hline NO & $\begin{array}{c}\text { Persentase } \\
(\%)\end{array}$ & Kategori \\
\hline 1 & $>2,5 \%$ & Layak \\
\hline 2 & $<1 \%$ & Tidak Layak \\
\hline
\end{tabular}

Melihat keadaan dan masalah yang ada maka pengukuran kinerja keuangan pemerintah daerah Kabupaten Tanah Bumbu dapat dilakukan dengan menganalisis laporan keuangan pemerintah Kabupaten Tanah Bumbu. Adapun alur kerangka berpikir dalam penelitian ini dapat dilihat dari gambar 1 . 


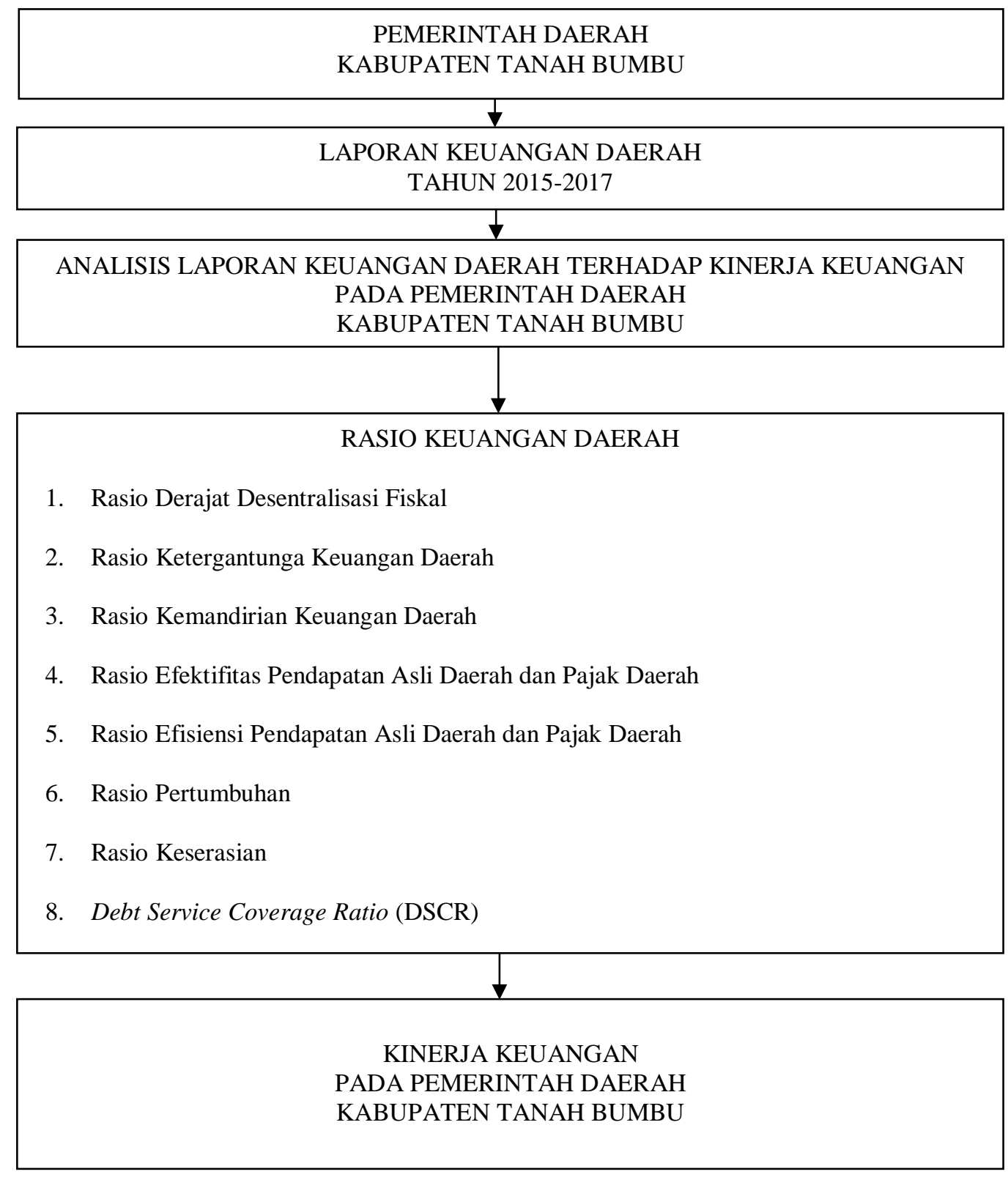

\section{Gambar 1. Model Kerangka Penelitian}

\section{Metode Penelitian}

Jenis penelitian yang dilakukan adalah penelitian diskriptif kuantitatif yang berusaha untuk menuturkan pemecahan masalah yang ada sekarang dengan menggunakan angka, mulai dari pengumpulan data, penafsiran terhadap data yang diteliti serta penampilan hasilnya.

Data Kuantitatif berupa Laporan Keuangan Pemerintah dapat diteliti secara langsung. Data kuantitatif dan kualitatif. Data kuantitatif adalah data berbentuk angka yang memiliki satuan hitung dan dihitung atau diukur seperti jumlah produksi dan penjualan, harga jual, biaya produksi dan biaya lain-lain. Sedangkan data Data kualitatif data yang tidak dapat diteliti secara langsung. Data ini menunjukkan kualitas atau mutu dari sesuatu yang ada berupa keadaan, 
proses, kejadian/peristiwa, dan lain-lain yang dinyatakan dalam bentuk pernyataan (perkataan) berupa gambaran umum Kabupaten Tanah Bumbu,

Sumber data yang digunakan dalam penelitian ini adalah data primer dan data sekunder. Data primer merupakan data hasil wawancara, maupun observasi langsung di lapangan. Sedangkan data sekunder diperoleh dari hasil laporan perusahaan, artikel, studi serta data organisasi yang terkait penelitian ini

Pengumpulan data dilakukan dengan interview atau wawancara dengan pemilik dan pengelola dari industri mengenai data-data yang akan peneliti analisis, berkaitan dengan kelayakan bisnis. Metode dokumentasi merupakan pengumpulan data baik angka maupun keterangan secara tertulis. metode dokumentasi adalah suatu cara untuk memperoleh data atau informasi tentang hal-hal yang ada kaitannya dengan penelitian, dengan jalan melihat kembali sumber tertulis yang lalu baik berupa angka atau keterangan.

Berdasarkan permasalahan yang ada, penelitian ini menggunakan teknik analisis diskiriptif kuantitatif. Metode ini menerapkan konsep perhitungan rasio keuangan, dengan menghitung rasio keuangan dari pos-pos dalam Realisasi Anggaran Pendapatan dan Belanja Daerah yang tertuang dalam Laporan Realisasi Anggaran Pemerintah Daerah. Metode ini digunakan untuk mengetahui indikator kinerja keuangan Pemerintah Daerah Kabupaten Tanah Bumbu dalam mengelola keuangannya dengan menggunakan rasio-rasio keuangan, diantaranya:

1. Rasio Derajat Desentralisasi

2. Rasio Ketergantungan Daerah

3. Rasio Kemandirian Daerah

4. Rasio Efektifitas Pendapatan Asli daerah dan Pajak Daerah

5. Rasio Efisiensi Pendapatan Asli Daerah dan Pajak Daerah

6. Rasio Pertumbuhan

7. Rasio Keserasian

8. Debt Service Coverage Ratio (DSCR)

\section{Hasil Penelitian dan Pembahasan}

Pada tanggal 27 Agustus 1849 nomor 8, perjuangan untuk membentuk daerah Kabupaten Tanah Bumbu menjadi suatu Kabupaten sendiri dimulai sejak tahun 1958 yang dimotori oleh para tokoh masyarakat Pagatan. Dengan kehadiran UU No.22 Tahun 1999 membawa angin segar terhadap cita-cita masyarakat Tanah Bumbu untuk mewujudkan wilayah Kabupaten Tanah Bumbu menjadi salah satu Kabupaten tersendiri yang terlepas daeri Kabupaten Induk (Kabupaten Kota Baru), sehingga untuk membentuk daerah Tanah Bumbu menjadi suatu Kabupaten

Kabupaten Tanah Bumbu yang berada di wilayah timur Kalimantan Selatan dan berbatasan dengan laut Jawa dibentuk berdasarkan Undang-Undang Nomor 2 Tahun 2003 tanggal 8 April 2003 tentang Pembentukan Kabupaten Tanah Bumbu dan Balangan di Provinsi Kalimantan Selatan dengan ibukota Batulicin, memiliki keanekaragaman hayati darat dan pesisir.

Rasio keuangan daerah yang digunakan dalam menganalisis kinerja keuangan yaitu dengan Rasio Derajat Desentralisasi Fiskal, Rasio Ketergantungan Daerah, Rasio Kemandirian Daerah, Rasio Efektifitas PAD dan Efisiensi Keuangan Daerah, Rasio Pertumbuhan, dan Rasio Keserasian dan Hasil dari analisis rasio dengan rekapitulasi rasio seperti ditunjukkan pada Tabel 9. 
Tabel 9. Tabel Rekapitulasi Rasio Kinerja Keuangan

\begin{tabular}{|c|c|c|c|c|c|c|}
\hline No & Rasio & 2015 & 2016 & 2017 & Rata rata & $\begin{array}{l}\text { Intepretasi } \\
\text { interval }\end{array}$ \\
\hline 1. & $\begin{array}{l}\text { Derajat } \\
\text { Desentralisasi } \\
\text { Fiskal }\end{array}$ & $9,29 \%$ & $7,94 \%$ & $11,28 \%$ & $9,45 \%$ & $\begin{array}{l}\text { Sangat } \\
\text { Kurang }\end{array}$ \\
\hline 2. & $\begin{array}{l}\text { Ketergantungan } \\
\text { Keuangan daerah }\end{array}$ & $87,02 \%$ & $89,44 \%$ & $88,30 \%$ & 88,30 & $\begin{array}{l}\text { Sangat } \\
\text { Tinggi }\end{array}$ \\
\hline 3 & $\begin{array}{l}\text { Kemandirian } \\
\text { Keuangan } \\
\text { Daerah }\end{array}$ & $10,68 \%$ & $8,93 \%$ & $12,77 \%$ & $10,70 \%$ & Kurang \\
\hline 4 & $\begin{array}{l}\text { Efektivitas PAD } \\
\text { dan Pajak Daerah }\end{array}$ & & & & & \\
\hline & $\begin{array}{l}\text { a. Efektivitas } \\
\text { PAD }\end{array}$ & $108,02 \%$ & $80,31 \%$ & $88,57 \%$ & $90,93 \%$ & $\begin{array}{l}\text { Cukup } \\
\text { efektif }\end{array}$ \\
\hline & $\begin{array}{ll}\text { b. Efektivitas } \\
\text { Pajak daerah }\end{array}$ & $94,28 \%$ & $76,53 \%$ & $81,74 \%$ & $85,53 \%$ & $\begin{array}{l}\text { Kurang } \\
\text { efektif }\end{array}$ \\
\hline 5 & $\begin{array}{lr}\text { Efisiensi } & \text { PAD } \\
\text { dan Pajak Daerah }\end{array}$ & & & & & \\
\hline & $\begin{array}{l}\text { a. Efisiensi } \\
\text { PAD }\end{array}$ & $4,37 \%$ & $1,63 \%$ & $1 \%$ & $0,21 \%$ & $\begin{array}{l}\text { Sangat } \\
\text { Efisien }\end{array}$ \\
\hline & $\begin{array}{l}\text { b. Efisiensi } \\
\text { Pajak Daerah }\end{array}$ & $17,22 \%$ & $6,47 \%$ & $2,57 \%$ & $8,11 \%$ & $\begin{array}{l}\text { Sangat } \\
\text { Efisien }\end{array}$ \\
\hline 6 & Pertumbuhan & & & & & \\
\hline & $\begin{array}{l}\text { a. Pertumbuhan } \\
\text { Pendapatan }\end{array}$ & $10 \%$ & $11,25 \%$ & $9,45 \%$ & $3,27 \%$ & Baik \\
\hline & $\begin{array}{l}\text { b.Pertumbuhan } \\
\text { Belanja }\end{array}$ & $-2,81 \%$ & $2,09 \%$ & $-48,92 \%$ & $-1,91 \%$ & $\begin{array}{l}\text { Kurang } \\
\text { Baik }\end{array}$ \\
\hline 7 & Keserasian & & & & & \\
\hline & $\begin{array}{l}\text { a. Belanja } \\
\text { Operasi }\end{array}$ & $63,96 \%$ & $67,07 \%$ & $68,79 \%$ & $66,59 \%$ & Baik \\
\hline & $\begin{array}{l}\text { b. Belanja } \\
\text { Modal }\end{array}$ & $22,39 \%$ & $19,73 \%$ & $16,57 \%$ & $27,68 \%$ & Sangat Baik \\
\hline 8 & $\begin{array}{lr}\text { Debt } & \text { Service } \\
\text { Coverage } & \text { Ratio } \\
\text { ( DSCR) } & \end{array}$ & $701,04 \%$ & $46,89 \%$ & - & $90,60 \%$ & Layak \\
\hline
\end{tabular}

Dari Rekapitulasi Perhitungan Rasio Kinerja Keuangan Pemerintah diatas dapat dijelaskan sebagai berikut:

1. Rasio derajat desentralisasi pemerintah daerah Kabupaten Tanah Bumbu tahun 2015-2017 menunjukan kemampuan pemerintah daerah dalam rangka meningkatkan PAD guna membiayai pembangunan daerahnya sendiri dengan persentase sebesar 9,45\%.

2. Rasio ketergantungan daerah Kabupaten Tanah Bumbu tahun 2015-2017 menunjukan masih sangat tingginya ketergantungan pemerintah daerah Kabupaten Tanah Bumbu terhadap bantuan pemerintah pusat dan provinsi dibandingkan dengan penerimaan daerahnya sendiri dengan memperlihatkan persentase keteragantungan daerah sebesar 88,30\%. 
3. Rasio kemandirian daerah Kabupaten Tanah Bumbu tahun 2015-2017 menunjukkan masih kurang dengan persentase kemandirian hanya sebesar $10,70 \%$, yang menunjukkan Pemerintah Daerah bahwa pemerintah daerah belum cukup mampu untuk membiaya sendiri kegiatan pemerintahan,pembangunan dan pelayanan kepada masyarakat,pemerintah daerah masih perlu campur tangan dari pemerintah pusat.

4. Rasio Efektifitas PAD Kabupaten Tanah Bumbu tahun 2015-2017 menunjukkan pemerintah daerah sudah efektif dalam merealisasikan PAD dari target yang sudah ditetapkan berdasarkan potensi rill daerah sebesar 90,93\%, hal ini menggambarkan tingkat kemampuan daerah semakin baik. Sedangkan dari rasio efektivitas pajak daerah menunjukkan kurang efektiv dengan persentase rata-rata sebesar $85,53 \%$ hal ini disebabkan pajak daerah yang memiliki kontribusi yang besar pada pajak daerah setiap tahun tidak terealisasi sesuai dengan target yang telah dianggarkan oleh pemerintah daerah.

5. Rasio efisiensi pendapatan asli daerah Kabupaten Tanah Bumbu tahun 2015-2017 sudah sangat efisien sebesar 0,21\%, yang artinya pemerintah daerah Kabupaten Tanah Bumbu telah sangat cermat dalam memperhitungkan biaya memperoleh pendapatan asli daerah. Kemudian untuk rasio efisiensi pajak daerah pemerintah Kabupaten Tanah Bumbu Tahun 2015 sampai dengan 2017 juga sangat efisien dengan persentase sebesar 8,11\%, artinya pemerintah daerah sudah sangat cermat dalam memperhitungkan biaya yang dikeluarkan untuk memperoleh pajak daerah, dan biaya yang dikeluarkan untuk memperoleh pajak daerah sangat kecil.

6. Rasio pertumbuhan kemampuan pemerintah daerah Kabupaten Tanah Bumbu tahun 20152017 dalam mempertahankan dan meningkatkan keberhasilanya terbukti pada penghitungan rasio pertumbuhan pendapatan yang menunjukkan skala interval baik sebesar 3,27\%, sedangkan rasio pertumbuhan belanja selama tiga tahun mengalami penurunan sebesar $1,91 \%$ yang disebabkan belanja modal mengalami pertumbuhan negatif akibat besar nya belanja operasi.

7. Rasio keserasian pemerintah daerah Kabupaten Tanah Bumbu tahun 2015-2017 menunjukkan bahwa pengalokasian dana lebih di dominasi oleh belanja operasi sebesar $68,79 \%$ dan belanja modal sebesar $27,68 \%$ dengan skala interval sangat baik.

8. Debt service coverage ratio (DSCR) memperlihatkan rasio DSCR sebesar 90,60\% lebih dari 2,5, ini menunjukkan kemampuan pemerintah daerah Kabupaten Tanah Bumbu untuk membayar kembali pinjaman dari Pemerintah Kota/Provinsi

\section{Kesimpulan} berikut:

Berdasarkan pada hasil dari penelitian ini, dapat dibuat serangkaian kesimpulan sebagai

1. Pemerintah Daerah Kabupaten Tanah Bumbu dilihat dari Derajat Desentralisasi Fiskal msih perlu memperhatikan untuk menyelenggarakan desentralisasi dengan mengoptimalkan potensi daerah (PAD) untuk menyelenggarakan pelayanan yang lebih baik.

2. Rasio ketergantungan keuangan daerah bahwa tingkat ketergantungan keuangan daerah Kabupaten Tanah Bumbu masih sangat tinggi.

3. Rasio kemandirian keuangan daerah diatas menunjukkan bahwa memiliki tingkat kemandirian keuangan daerah untuk membiayai sendiri kegiatan pemerintahan,pembangunan dan pelayanan kepada masyarakat,pemerintah daerah masih perlu campur tangan dari pemerintah pusat.

4. Rasio Efektivitas Pendapatan Asli Daerah menunjukkan bahwa Kabupaten Tanah Bumbu dalam merealisasikan Pendapatan sudah efektif 
5. Rasio Efisiensi pendapatan asli daerah pemerintah telah sangat cermat dalam memperhitungkan biaya memperoleh pendapatan asli daerah. Kemudian untuk rasio efisiensi pajak daerah pemerintah Kabupaten juga sangat efisien.

6. Rasio pertumbuhan kemampuan pemerintah daerah pada penghitungan rasio pertumbuhan pendapatan yang menunjukkan skala interval baik, sedangkan rasio pertumbuhan belanja mengalami penurunan disebabkan karena belanja tahun sebelumnya tidak prioritas untuk tahun sekarang.

7. Rasio keserasian belanja operasi dan belanja modal sangat baik, namun alokasi dana lebih banyak digunakan untuk belanja operasi dibandingkan belanja modal atau pembangunan.

8. Debt service coverage ratio (DSCR) memperlihatkan rasio DSCR ini menunjukkan kemampuan pemerintah daerah Kabupaten Tanah Bumbu untuk membayar kembali pinjaman dari Pemerintah Kota/Provinsi

9. penurunan sebesar $-1,91 \%$ yang disebabkan belanja modal mengalami pertumbuhan negatif akibat besar nya belanja operasi.

10. Rasio keserasian pemerintah daerah Kabupaten Tanah Bumbu tahun 2015-2017 menunjukkan bahwa pengalokasian dana lebih di dominasi oleh belanja operasi sebesar $68,79 \%$ dan belanja modal sebesar $27,68 \%$ dengan skala interval sangat baik.

11. Debt service coverage ratio (DSCR) memperlihatkan rasio DSCR sebesar 90,60\% lebih dari 2,5, ini menunjukkan kemampuan pemerintah daerah Kabupaten Tanah Bumbu untuk membayar kembali pinjaman dari Pemerintah Kota/Provinsi

Berdasarkan hasil penelitian di atas maka ada beberapa saran yang dikemukakan, yaitu :

1. Pemerintah perlu meningkatkan PAD agar tingkat ketergantungan daerah berkurang dengan cara memperluas basis penerimaan, salah satunya dengan cara mengidentifikasi pembayaran pajak potensial, mengembangkan wisata alam yang ada di Kabupaten Tanah Bumbu, budaya serta perdagangan, meningkatkan pembangunan .

2. Bagi peneliti selanjutnya yang akan melakukan penelitian terhadap kinerja keuangan pemerintah daerah setiap tahunnya dan dapat membandingkan dengan daerah lainnya.

\section{DAFTAR PUSTAKA}

Aulia, Zikri, 2017, Analisis Kinerja Keuangan Pemerintah Daerah Kabupaten Aceh Timur Periode 2011-2015. Skripsi Program studi strata I Dapertemen Akuntansi. Fakultas Ekonomi, Universitas Sumatra Utara. http://repositori.usu.ac.id/bitstream/handle/ 123456789/1792/130503038.pdf?sequence=1\&isAllowed=y (diakses 22 Juli 2018)

Hery, 2015, Analisis Laporan Keuangan Pendekatan Rasio Keuangan, CAPS, Yogyakarta.

Mahmudi, 2016, Analisis Laporan Keuangan Pemerintah Daerah Edisi Ketiga, UPP STIM YKPN, Yogyakarta..

Faud,Muhammad,Ramli,2016,Analisis Laporan Keuangan Pemerintah Daerah,Ghalia Indonesia, Bogor

Banga,Wempy,2017,Administrasi Keuangan Negara dan Daerah,Ghalia Indonesia,Bogor

Yulistiana Devi, 2018, Analisis Kinerja Pengelolaan Anggaran Pendapatan Dan Belanja Daerah Pada Pemerintah Kota Banjarbaru, Skripsi Jurusan Akuntansi, STIE PANCASETIA, Banjarmasin.

Prasetyo, Pranoto, Dwi, 2018, Analisis Kinerja Keuangan Pemerintah Daerah Kabupaten Tanah Laut Tahun 2017,Skripsi Jurusan Akuntansi,STIE PANCASETIA,Banjarmasin 
Republik Indonesia, Peraturan Pemerintah Dalam Negeri Nomor 13 Tahun 2006 tentang Pedoman Pengelolaan Keuangan Daerah.

Peraturan Pemerintah Nomor 71 Tahun 2010 tentang Standar Akuntansi Pemerintahan.

Peraturan Menteri Dalam Negeri Nomor 64 Tahun 2013 tentang Penerapan Standar Akuntansi Pemerintahan Berbasis Akrual pada Pemerintah Daerah.

Undang-Undang Nomor 17 Tahun 2003 tentang Keuangan Negara.

Undang-Undang Nomor 32 Tahun 2004 tentang Pemerintahan Daerah. 